\title{
The image of the lifeworld in philosophy and fiction narratives
}

\author{
Peter Ziak - Uzakbayeva Sakhipzhamal - Merey Zeinesh - Alua \\ Tanzharikova - Tulebike Kulgildinova
}

DOI: 10.18355/XL.2022.15.01.019

\begin{abstract}
The study focuses on the concept of the lifeworld, which was developed by representatives of phenomenological philosophy and philosophy of existentialism. The lifeworld arises as a pre-scientific understanding of the world as a certain horizon of knowledge, interrelationships and unifying meaning. Because such an understanding is tied to subjective experience, it escapes scientific descriptions, that explain the world mainly on the basis of objective facts. The aim of this study is to explain why literary narratives can represent the lifeworld better than its scientific interpretations. Fictional narratives can better capture the temporal, dynamic, but also paradoxical nature of the world's understanding, so they reach the reader more deeply and intimately. We define the process of reading as an activity associated with the semiosis of the lifeworld, which has a fictional essence from a logical-ontological point of view, but part of the reader's cooperation is also the updating of the real world and personal experiences. Text strategies even take this into account and expect the reader to understand the fictional world similarly to the real world.
\end{abstract}

Key words: lifeworld, phenomenology, fictional narrative, reception, aesthetic experience

\section{The concept of the lifeworld in philosophy}

At the end of his academic career, the German philosopher Edmund Husserl gave lectures on the topic of the lifeworld (in German Lebenswelt) in Prague and Vienna (1935-1936), which he later edited into a comprehensive monograph The Crisis of European Sciences and Transcendental Phenomenology. The subtitle of the work An Introduction to Phenomenological Philosophy -refers not only to the reinterpretation of the phenomenological method, but the work also aspired to propose a new basis for scientific research on the foundations of philosophy. In Husserl's view, the return to philosophy constitutes the way how to overcome the crisis of the meaning of scientific achievements by reconnecting the abstract systems of thinking with the empirical reality and pre-scientific experience. In line with the phenomenological creed "back to the things themselves", Husserl called for a return to the phenomenal nature of the world (how the world presents itself to consciousness; how it appears in its phenomenality), that should be ensured by phenomenological philosophy.

Transcendental phenomenology should have made available the original realm of constituting the world in transcendental subjectivity through the so called epoché or phenomenological reduction - the general thesis on the existence of the world is provisionally closed and the world is looked at as a phenomenon in consciousness. According to phenomenology (which, in this aspect, follows up on Kant's transcendental idealism), our sensory opinion is conditioned by a priori structures and cognitive patterns of subjectivity. These are mainly spatio-temporal and causal relations, which condition our perception of the world, and demarcation of the perception spectrum between the pole "I" and the pole "the world" as escaping horizons of what is being shown. The whole world as an escaping horizon cannot be, by its nature, accessible for experience, nevertheless, based on our pre-scientific experience, we understand something like the world and we place ourselves into this whole. Philosophy should relate the individual realms of knowledge to this imaginary 
unity. Already in Socrates' philosophy, the fate of philosophic or exploratory life was perceived as an infinite project, having purpose despite its incompleteness, since it provides rational life with a certain regulation, direction and unity. Galileo's mathematization of nature and its scientific instrumentalisation (nature is mainly a material designed to test scientific hypotheses) result into an increasing gap between the scientific interpretation of the world and the subjective experience of the individual: "It was a fatal omission that Galileo did not retrospectively inquire the original sensory act, which, when performed as an idealization on the primordial ground of all theoretical and practical life - the immediately illustrative world (and here especially the empirically illustrative world of bodies) - creates ideal geometric shapes. (...) Indeed, in the case of inherited geometry, these acts were no longer performed live, let alone theoretically realised by reflection as methods that internally create a sense of exactness." (Husserl, 1972 : 70 - 71).

Once the scientific development loses contact with the pre-scientific understanding which is based on experience, it is no longer relevant for life, or even often becomes inaccessible for common understanding. This does not have to apply to the outputs and products of science as such, however, scientific direction can be detached from life circumstances or it can even turn (unpurposefully) against humanity (industrial revolution, atomic bomb, bioethics, etc.). In the post-war ambiance, Husserl himself expressed this idea in the following statement: "In our vital need, as we hear, science has nothing to say to us. It excludes in principle precisely the question which man, given over in our unhappy times to the most portentous upheavals, finds the most burning: questions about the meaning or meaninglessness of this whole human existence." (Husserl, $1972: 27-28$ ).

The phenomenological turn to experience is a response to scientific positivism, which pushed the original understanding of the world as we immediately experience it to the margins of knowledge. We have to add that not only in philosophy, but also in art and literature, there was a shift form the positivistic conception towards the subject and his experience. Although in art, of course, this shift was not supposed to be systematic and general. As an example could serve the crisis of the naturalistic novel and the rise of modernism and psychologism, which integrated into the narrative what realists and naturalists deliberately distanced themselves from: the subjectively colored image of the world and the personal identity (cf. Raimond, 1981 : 127).

The development of the post-Husserlian phenomenology was not homogenous and there have been several revisions of its methods and underlying principles. We will not deal with them on an individual basis, however, we will at least point to the (already mentioned) unfeasibility of a philosophical project, which, in Husserl's case, should have been purifying cognition from prejudices and theoretical constructs and revealing the original source of the meaning of the world as a unifying whole (the world that gives meaning). For example, Jacques Derrida pointed out that language itself, which neither phenomenology can escape from, is never clean of cultural sediments and prejudices, and the act of writing itself is always a certain departure from the original records of consciousness (cf. Derrida, 2003 : 97). We will probably never know the lifeworld as a precisely described transcendental phenomenon as it represents a constantly shaping, culturally and linguistically sedimental concept. For example, Michal Ajvaz defines it as follows (using Patočka's term "natural world"): "Experience constitutes a world of challenges, everything arises as a response to a challenge, to the provocation of another, and it is in itself a challenge and provocation leading to the emergence of another. Thus, the natural world is not a peaceful garden of Eden of unspoiled naturalness, protected from alienation, but rather a drama, a high game of meaning. It is a realm where meaning

XLinguae, Volume 15 Issue 1, January 2022, ISSN 1337-8384, eISSN 2453-711X 
happens; and this happening is related to the dynamic nature of meaning, with meaning emerging as a directional schedule of this expression, and at the same time transcending it, creating an aura of new possibilities around these configurations, which will be explicated in new configurations, and, at the same time, be born from their expression" (Ajvaz, $2010: 45$ ).

Thus, the lifeworld is a realm of pointing to always already somehow situated and attuned consciousness. Moreover, consciousness itself is temporal and immersed in the world. However, Heidegger pointed to the fact that even this consciousness concerned by the world is, at the same time, always concerned by its own being - whether it escapes from its own being, sinks into the world, objectifies in it or, on the contrary, asks about its own being and challenges it. It always arranges itself into certain possibilities grasped from the fundamental perspective. Heidegger designates the existence of a man as "a concern", pointing out that in the most fundamental questions of understanding the world and one's own situation, man always relates to himself and his finite existence. This underlying structure of human existence reveals itself especially in anxiety: "Anxiety as an essential possibility of staying (being-here of a man - note P. Ž.), together with the stay itself, which is unlocked in it, provides phenomenal ground for an explicit grasp of the original integrity of the stay's being. Its being is revealed as a concern" (Heidegger, 2008 : 216). Man is a being who is concerned with this very being in his existence, and thanks to this, he also has the opportunity to ask a question about his meaning: "Therefore, the stay takes multilateral priority over any other being. The first priority is ontic: this being is in its essence determined by the existence. The second priority is ontological: based on the fact that the stay is determined by the existence it is in itself 'ontological'. Nevertheless, the stay originally also includes - as a constituent of understanding existence - understanding the existence of all being which does not have the character of stay. The stay therefore has the third priority as an onticoontological condition for all ontologies. Thus, it was demonstrated that, in terms of our ontological questioning, we have to primarily address the stay before any other being" (Heidegger, $2008: 29-30$ ).

In his central work Being and Nothingness, Jean-Paul Sartre followed up on Heidegger's analysis of human existence structure, explaining the paradox of man's being as "being for itself" (être pour soi), which, however, wants to be "being in itself" (être en soi); this identification being always only imaginary (cf. Sartre, 2006 : 132). The negativity in the form of the permanent concern for oneself was already pointed out by Hiedegger and Sartre specifically named the procedural, temporal and relational nature of being as "nothingness". Man's being cannot be determined in the form of essence because in this way, man does not understand his being in the pretheoretical perception. Being is problematic and Sartre's analyses portray it as a constant drama, manifested by a desire for recognition, empowerment, selfdetermination, and decision-making. Sartre derives morality from this underlying ontological character of being in the form of a rather pessimistic picture of freedom as a necessity to establish moral principles through one's own decisions and actions because there is no metaphysically given moral law anyway: "To be means for the being for oneself to annihilate the being in itself, which it is. Thus, freedom can be nothing else than this annihilation itself. Through it, the being for itself escapes its being and its essence, and is therefore still something other than what could be said about it and something other than what could be named" (Sartre, $2006: 509$; on this issue, see also Martin - Rojas - Kralik, 2020).

Science that explores the world in the form of objective things or processes cannot explain man's being in a similar way as the latter is constantly evolving towards what it is not (it is a being that understands itself in time and in terms of time). The phenomenological concept of the world represents a relation to the whole, 
understanding and interpretation (speech). It is not merely a state of things, but also disposition, possibilities and challenges, changing interests in this or that fragment of the world against the background of its context or immediate circumstances. In the next part, we will explain how literary fiction narratives represent models of the lifeworld, as defined above.

\section{Representation of the lifeworld in narrative texts}

From the logico-ontological perspective, the worlds that generate narrative fiction texts as versions of possible worlds can be further defined as specific possible worlds accessible via the semiotic channel of the text (cf. Doležel, 2003 : 34). Theoreticians of fictional worlds emphasise that the truth value of statements in a fictional text refers to their validity in a fictional, not in the actual (real) world. This, of course, does not disqualify fiction in any way since every reasonable reader understands this fact and reads the narrative, even though it refers to the world of fiction. Generally speaking, people have no problem paying attention to the imaginary states of the world or alternative versions of the actual world, one can even speak of common pleasure of imagination or fantasy.

Fictional worlds are updated possible worlds with their own modal structure, which means that the validity of statements about a specific fictional world is determined by information provided in the text. However, the very fiction of the discourse as such is only rarely derived from the statements in the text - in the majority of cases, it is, on the contrary, anticipated at the beginning of reception. On this point, Ruth Ronen says: "Since the fictionality of texts cannot be connected $a$ priori with any particular set of textual features or with a stably given group of texts, their is room for a pragmatic definition of fiction, which should take into account a holistic system of world-building conventions, cultural beliefs, and reading procedures" (Ronenová, 2006 : 106).

The reader accepts that the texts speaks of a non-existent world, but it is the reader who creates this world in his consciousness - not so much for its factual recognition as for the enjoyment of the reception process and the creation of reading hypotheses. One of the literary conventions which also governs text strategies is searching for coherence in the text during its reception. As readers, we presume that the text is filled with structural components, among which we look for logical and causal relations. Lotman also claims that "the literary world is an intricately built world. All its elements are semantic elements." (Lotman, 1990 : 23). Cognitive processes and interpretation models used for understanding the current world are basic leading instruments for understanding text. Literary narratives build their aesthetical effect on them, for they are able to elicit affective reactions in the reader: "Mental accessibility of fiction is questionable, since it assumes mixing of normal emotions related to admiration or fear with desires, as well as aesthetical interests. When we meet with Anna's unfortunate destiny (the author refers to Anna Karenina from Tolstoy's novel - note P. Ž.), our physical reaction correlates with aesthetic distance. Such kind of duality is adequately covered by the term katharsis: blending of sympathy and terror with pleasure and relief. This duality defines the nature of statements that are supposed to influence recipient's reaction to fiction" (Ronen, 2006 : 112).

An intentional stimulation of recipient's complex cognitive apparatus including emotional manifestations, is a part of pragmatic text design (the way it is supposed to impact the reader). It is enabled by identification of entities, mental processes, voices or consciousness in fiction, as well as identification of realia, cultural codes, rules and norms, which, if the text does not contradict that, are evaluated by the recipient from the viewpoint of his knowledge and experience related

XLinguae, Volume 15 Issue 1, January 2022, ISSN 1337-8384, eISSN 2453-711X 
to the current world or other texts. On the one hand, semiosis is influenced by the awareness of fictional aspect of the text, and on the other by mimetic modelling of fictional world. Mimesis does not mean that fictional entities and events refer to the real and existing entities and events, as fictional worlds theorists try to simplify: "Basic step of mimetic interpretation is to assign a real prototype to a fictional entity" (Doležel, $2003: 21$ ). The reader is although aware that they align their images and hypotheses with non-existent world (in such a specific form depicted by fictional text). The reader thinks about it in a similar way as about the current world (and it also concerns the ability to react emotionally to narrated situations). Modelling of fictional or simulated worlds is another way to create coherent models of reality as such: "We can create models from non-existent entities and develop the most fantastic worlds, but all these entities and worlds will still conform to our idea of "being real", for our ability to create representations still conforms to the environment where we were brought up and where we continue to live" (Schaeffer, 1999 : 218).

Semantics of fictional worlds often ignores the abovementioned pragmatic aspects of texts, for they are related to the reception process itself as a final state of fictional world. Experience reception is (fortunately for aficionados of narratives) not limited to the exact description of fictional world status, or in formal analysis of texture. Aesthetic experience of reading is caused by the combination of narrative and hermeneutic interest (cf. Jouve, 2019 : 89), in other words - interest in plot development and understanding narrative, world, characters and their problems. Both interests naturally encourage the reader to create hypotheses on narrative development, while it does not concern only intellectual, but also emotional response to the text (tension, curiosity, fear, hope, etc.). The process itself (reading) causes aesthetic experience, hence its aim is not to finish it as soon as possible and achieve full cognition of fictional world or fabula, but to remain in it - at least until it still pleases narrative and hermeneutic interest (detailed analysis of aesthetic experience can be found in Schaeffer, $2015: 247$ ).

Semiosis of narrative text is also interesting not only as a full description of fictional world, but also as a process. Narrative has its semantic dynamics, development or energy, often pointed out by the representatives of Czechoslovak structuralism (cf. Mukařovský, 2007 : 372; Jankovič, 2005 : 33). Regarding literary narratives, the interest to obtain new information from the text is related to the interest to deeper understand the characters and their life, leading to deep levels of text (like actant and ideological structures). František Miko even connects aesthetic effect of literature first of all with personal (empathetic) interest of the reader to solve the presented problem of life: "Aesthetic experience is caused first and foremost by the duality of terms "problem of life" and "its solution". Aesthetic experience is fundamentally polarized, contrastive: the first part is represented by the feeling of dissatisfaction, worry, tension, the need not to settle and not to give up, the second part by the feeling of solving the problem and of edifying relief. The structure of a literary work is similarly polarized considering tension and lack of tension" (Miko, 1978 : 58). Besides understanding thematic core of narrative, the concept of tension and lack of tension by Miko implies personal feelings, stances and values.

Semantic density mentioned by Lotman, as well as values often reflected in narrative uplift literary narratives to the level of relevant models of reality - even more, since besides factual descriptions of fictional realities, they imply heterogeneous perspectives of perception, motivation of interest and value, life explanation of the world: "Literary work does not lead towards anything, as we mentioned, to something outside it, to no obvious goal. It is possible to narrate a story only about something that is outside the sign itself. A literary sign, contrary to informative sign, does not conform to a simple description of external things, i.e., it is not a tool. It is not things - despite depicted in the work - but a certain attitude 
towards things, a certain proportion of one towards the whole reality surrounding them, not just to one that is directly shown, what enforces understanding between people" (Jankovič, 2005 : 79). Jankovič points out that works of art (or even art in general) offer invaluable source of humanized views of the world. Besides various narrative plots, there is a high variability of linguistic expression being in contrast with the exact and conceptual interpretation of science. Artistic narratives contain languages of life and familiar communication situations, as well as narrator's language as simulation of human consciousness and somehow situated viewpoint of understanding - as we know it from our real life.

\section{Phenomenology of Reading and Semiosis of Lifeworld (synthesis)}

In previous interpretation, we pointed out that the attractiveness of literary narratives is not caused by the ability to describe the situation, but rather by the ability to describe acquirement of the world from a certain interpretation and a specific life situation. Reflexive-descriptive element in narrative is present just as epic element, which only directs the reader's attention to the plot structure and the development of character's destiny. The reader looking for a deeper hermeneutic understanding is obliged to analyse and reassess information in text, which often does not offer explicit statements regarding deeper knowledge. Most theories about deeper levels of text (that do not necessarily need to be supported in the text, but they might result from other statements) are based on the reader's interpretation, which is often unreliable. To successfully cooperate with the text, the reader must constantly apply knowledge of the real world and knowledge obtained from other texts to their interpretation. This competence is a key part of cooperation with the text, for it enables the reader to create coherence between information gaps (a text contains a lot of them, since it cannot and does not strive to offer a complete description of the world). In this elementary process of interpretation, the real world and experience of the reader enter the process of semiosis, to further conform to transformation and recontextualization provoked by the text. The ability to apply extratextual context in reception is a common part of textual strategies creating a model reader.

During investigation of narrative text from the aesthetic viewpoint, we cannot exclude the dynamic nature of reception having time and procedural character, meaning that reception has certain (and mostly discontinuous) duration accompanied by realization based on alternation of figure and background - new information emerge backgrounded by the old ones and those become a background for another scheme (cf. Iser, 1980 : 92). The relation of figure and background does not concern only linear structure of information in the text itself, but also the extratextual context updated in reception. In case of literary narratives, the time and procedural mental activity is tightly linked to the development of story, thus we can say that during semiosis of the narrative we experience destiny along with characters in similar time extraction from linear flow as described by Heidegger: "Originally, time resembles temporalizing temporality, which lays ground for Concern structure. Temporality is fundamentally ecstatic" (Heidegger, 2008 : 370). As we mentioned above, according to Heidegger, being of Dasein can be characterized as concern. Concern is originally constituted as temporal structure, meaning that Dasein is related towards its own being always in a certain lag, but also in advance (being-towards-death, finitude), thus it steps out of the present and its assumed momentariness - the present is always related to the past and future that is final.

Fictional narratives depict the experience of time not only at thematic level, but also on the level of narrative structures through which they evoke a certain perception of time or extraction from the time flow (ecstasy) in recipient's consciousness. Current narratological conceptions enrich traditional structural

XLinguae, Volume 15 Issue 1, January 2022, ISSN 1337-8384, eISSN 2453-711X 
approach to narrative as a closed structure with dynamic aspects of narration. Raphaël Baroni's narratological concept, who besides the interpretation of narrative procedures focuses a lot at pragmatic aspects, hence reception, serves as an example: "Text construction based on tension enhances our attention to places where narrative provokes its recipient, directs their expectations to the promised but postponed solution - to the denouement marked by uncertainty during the whole interpretation. In other words, rising action and denouement, which construct the plot of the narrative, represent first of all stages of interpretation process and their purpose is to build tension" (Baroni, 2007 : 41). The perception of tension in narrative signals the occurrence of the well-known effect of immersion into the plot, thus to positive course of aesthetic experience (marked by the will to continue in reception).

The reader who "experiences" the narrative (as often said in natural speech), updates their values and stances, as well as repertoire of affective expressions in the form of emotional reactions to fictional (simulated, but believable) impulses. Reading does not represent a side activity in relation to the real world, but the process of intense reflection of own mental and physiological expressions, for literary narratives constantly instigate these reactions. Let us not forget that we talk about narrative as a mental construct edited by information in the text, but it is a product of the reader as such. From logical-ontological viewpoint, the fictional text probably refers to the fictional world and we must derive its state from strictly given structure of meaning, however, from phenomenological viewpoint, reading relates to a reader's lifeworld much deeper. Reading is not objective and unbiased identification of fictional world, but its life-motivated adoption and comprehension. A competent reader is able to distinguish statements about the fictional world from statements about the real world. In parallel, the reader is able to take seriously problems depicted in fiction as it would concern real problems. Literature enables the reader to confront themselves with attitudes and perspectives of perception different from their own, although they still concern human views, understandable and vitally close ones. In this sense, literary narratives represent a constant update of lifeworld, which is a world of our personal experience and pre-scientific understanding, but a world of collective images of reality and shared experience and knowledge as well. Representation of lifeworld in literature remains in intimate touch with pre-scientific experience - despite it offers incomplete and often contradictory cognition, it is able to constantly refer back to the question of purpose consciously or unconsciously sought by the characters in their life (just as real people).

\section{Bibliographic references}

Ajvaz, M. (2010). K cemu je dobry pojem prirozeneho sveta. In: Velicky, B. Trlifajova, K. \& Kouba, P. (eds.) Spor o prirozeny vet. Prague: Filosofia, 19-53. ISBN 978-80-7007-317-9.

Baroni, R. (2007). La tension narrative: Suspense, curiosite et surprise. Paris: Editions du Seuil. ISBN 978-2-02-090677-7.

Derrida, J. (2003). Tradice vedy a skryvani smyslu. Prague: Oikonmenh. ISBN 807298-059-9.

Dolezel, L. (2003). Heterocosmica: Fikce a mozne svety. Prague: Karolinum. ISBN 80-246-0735-2.

Heidegger, M. (2008). Byti a cas. Prague: Oikoymenh. ISBN 978-80-7298-048-3.

Husserl, E. (1972). Krize evropskych ved a transcendentalni fenomenologie: Uvod do fenomenologicke filosofie. Prague: Academia.

Iser, W. (1980). The Act of Reading: A Theory of Aesthetic Response. London: The Johns Hopkins University Press. ISBN 978-0-8018-2371-8.

Jankovic, M. (2005). Cesty za smyslem literarniho dila. Prague: Karolinum. ISBN 80246-1013-2. 
Jouve, V. (2019). Pouvoirs de la fiction: Pourquoi aime-t-on les histoires? Paris: Armand Colin. ISBN 978-2-200-62709-6.

Lotman, J. M. (1990). Struktura umeleckeho textu. Bratislava: Tatran. ISBN 80-2220188-X.

Martin, J., Rojas, A. M. \& Kralik, R. (2020). The Problem of The "Individual" Concept in The Kierkegaard's Journals. In: European Journal of Science and Theology 16(2), 39-46. ISSN 1338-5615.

Miko, F. (1978). Esteticka komunikacia. In: Miko, F., Popovic, A.: Tvorba a recepcia: Esteticka komunikacia a metakomunikacia. Bratislava: Tatran, 15-236.

Mukarovsky, J. (2007). Studie I. Brno: Host. ISBN 978-80-7294-239-8.

Raimond, M. (1981). Le roman depuis la Revolution. Paris: Armand Colin.

Ronenova, R. (2006). Mozne svety v teorii literatury. Brno: Host. 80-7294-180-1.

Sartre, J.-P. (2006). Byti a nicota: Pokus o fenomenologickou ontologii. Prague: Oikoymenh. ISBN 978-80-7298-250-9.

Schaeffer, J.-M. (1999). Pourquoi la fiction? Paris: Editions du Seuil. ISBN 978-2-02034708-2.

Schaeffer, J.-M. (2015). L'experience esthetique. Paris: Gallimard. ISBN 978-2-07039980.

Words: 4607

Characters: 30649 (17,03 standard pages)

PhDr. Peter Žiak, PhD.

St. Cyril and Methodius University, Faculty of Arts

Nám. J. Herdu 2, 91701 Trnava

Slovakia

peterziak90@gmail.com

Uzakbayeva Sakhipzhamal, dr.

Department of pedagogy and psychology

Ablai Khan Kazakh University of International Relations and World languages

050020, Muratbayev street, 200, Almaty

Kazakhstan

Merey Zeinesh

L.N. Gumilyov Eurasian National University

Satpayev Str., 2

010008, Nur-Sultan

Kazakhstan

Alua Tanzharikova dr.

director of Institute philology and multilingual eduction

Kazakh National Pedagogical university named after Abay

Dostyk avenue, 13, 050050

Kazakhstan,

Tulebike Kulgildinova dr.

Department of Internationnal Communication

Ablai Khan Kazakh University of International Relations and World languages 050022, Muratbayev street, 200, Almaty

Kazakhstan

XLinguae, Volume 15 Issue 1, January 2022, ISSN 1337-8384, eISSN 2453-711X 